\title{
IMPROVING VOCATIONAL TEACHERS' INNOVATIVENESS THROUGH PERSONALITY AND TRANSFORMATIONAL LEADERSHIP DEVELOPMENT
}

\author{
Muthahharah Thahir a*, Aan Komariah b , Cucun Sunaengsih ${ }^{\mathrm{c}}$, Ima Rahmawati d. \\ a* Program Studi Administrasi Pendidikan Universitas Pendidikan Indonesia \\ Jl. Dr. Setiabudhi no. 229, Bandung, muthahharah_thahir@upi.edu

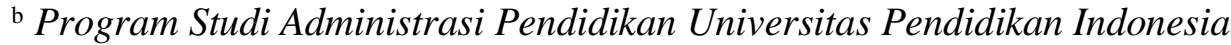 \\ Jl. Dr. Setiabudhi no.229, Bandung, aan komariah@upi.edu \\ c Program Studi Pendidikan Guru Sekolah Dasar Universitas Pendidikan Indonesia \\ Jl. Raya Cihampelas No. 96, Bandung Barat, Indonesia, gilang.dawous@ gmail.com \\ ${ }^{d}$ Program Studi Administrasi Pendidikan Universitas Pendidikan Indonesia \\ Jl. Dr. Setiabudhi no. 229, Bandung, cucunsunaengsih@upi.edu
}

\begin{abstract}
The success of a vocational school in achieving its goals is greatly determined by how innovative the school members, which include teachers as frontliners in educational quality, are. Innovativeness does not emerge and develop in vacuum. It is closely related to other factors such as personality and transformational leadership. 238 private vocational high school teachers in Bogor City were selected as sample in the present study, which implemented quantitative approach using survey method.

Based on the findings, it was concluded that: (1) there was a positive correlation between personality and innovativeness, with coefficient of correlation (ry1) of 0.318 and coefficient of determination (ry12) of $10.14 \%$ through regression equation $\hat{Y}=47.669+0.597 \mathrm{X} 1$, (2) there was a positive correlation between transformational leadership and innovativeness, with coefficient of correlation (ry2) of 0.261 and coefficient of determination (ry22) of 6.83\% through regression equation $\hat{Y}=84.113+0.207 \mathrm{X} 2$, and (3) there was a positive correlation between personality and transformational leadership variables, collectively, and innovativeness variable, with coefficient of correlation (ry12) of 0.379 and coefficient of determination (ry122) of $14.37 \%$ through regression equation $\hat{Y}=33.492+0.165 \mathrm{X} 1+$ $0.524 \mathrm{X} 2$. Teachers' innovativeness can be improved through personality development. The roles of headmasters' transformational leadership will modify teachers' behavior, allowing the latter to work more than what is expected and to improve their performance. It is a form of teachers' empowerment to develop skills and trusts, and to create a better school culture that encourage innovativeness and creativity development. In other words, personality and transformational leadership development can improve teachers' innovativeness.
\end{abstract}

Keywords: Personality, Transformational Leadership, Personality and Innovativeness.

\section{INTRODUCTION}

Education is a strategic means to improve the quality of human resources, which are determining factor of development. A nation's pride and quality depend greatly on its quality of education. In the context of Indonesia, education quality improvement is one of the goals of national education development and is an integral part of the effort to improve the quality of Indonesian people as a whole. Article 1 of Chapter I of the Act No. 20 Year 2003 on the National Education System stipulates that 'Education means conscious and well-planned effort in creating a learning environment and learning process so that learners will be able to develop their full potentials for acquiring spiritual and religious strengths, develop self-control, personality, 


\section{No. 1 June 2018}

intelligence, morals and noble character and skills that one needs for him/herself, for the community, for the nation, and for the State.' With all due respect to all other components in education system, the educators or teachers are a very essential component in determining the quality of the students.

Teachers are on the center of every educational reform aimed towards quality improvement. Every educational effort such as curriculum changes, teaching methods development, and facilities and infrastructure provision, will only mean something if it involves the teachers. In addition, teachers are positioned as front-liners in education process since they play a strategic role in creating competent and high-quality graduates to satisfy the needs for professional human resources. Therefore, teachers' quantity and quality must be increased and improved in accordance with the current and future needs.

Article 20 (a) of Chapter IV in the Act No. 14 Year 2005 on Teachers and Lecturers stipulates that the standard of teachers' performance in doing their professional duties entails the responsibility for teachers to plan the lesson, implement a high-quality learning process, and assess and evaluate learning results. These primary duties of teachers are realized in learning activities, which demonstrate teachers' innovativeness. Improving teachers' innovativeness will positively affect the quality of output yielded in education and learning processes. The quality of education and the quality of graduates are often considered as dependent on teachers' roles in managing learning components they use in the learning process they implement.

Vocational High School (VHS) is one of several types of secondary education institution in Indonesia. Its education is designed to equip students with necessary practical skills to enter workplaces. VHS is a formal education with particular training program to guide its students to become graduates who are ready to professionally work in their specific fields, in public or private sector. Not only do VHS graduates in Indonesia have to be prepared for professional work, they also have to be able to compete with foreign workforce. Hence, Vocational High School must possess qualified staff (teachers) who can adapt to global changes.

Considering that the goal of education is to produce high quality graduates, in terms of knowledge, competency, and personality, teachers' innovativeness is crucial. If a teacher is not innovative, the learning process in his or her class will be unengaging and uninteresting, causing students to lose focus and concentration, which will harm the successful achievement of learning goals. Unsuccessful achievement of learning goals will produce unsuccessful graduates, or at least graduates who are not as expected. Therefore, teachers' innovativeness is a key to an educational institution's success in producing the expected graduates.

A preliminary survey on 30 teachers who are working in 10 private VHS in Bogor City indicates that private vocational high school teachers in Bogor City have problems with innovativeness, which involves product innovativeness, process innovativeness, and service innovativeness. The results of the preliminary survey are as follows:

1. Some teachers have problems with innovativeness in planning lessons. 57\% of the surveyed teachers does not develop lesson plans and 50\% teachers makes lesson plans which are irrelevant to the latest global development, in terms of both basic knowledge and implementation.

2. Some teachers have problems with innovativeness in learning media. $63 \%$ of teachers still has not used internet to explore various teaching and learning resources.

3. $90 \%$ of teachers has problems with innovativeness in procedures for teaching; they do not implement project-based teaching methods.

4. Some teachers have problems with innovativeness in teaching models and methods. $90 \%$ teachers is not accustomed to implementing inquiry-based teaching 
Muthahharah Thahir, et al. /Journal of Educational Administration Research and Review/Vol. 2

\section{No. 1 June 2018}

methods (e.g. scientific method, discovery method).

5. $60 \%$ of teachers has problems with innovativeness in approaching problems pertaining to their students. These teachers have not given the students opportunities to implement their creative ideas.

6. $87 \%$ of teachers has problems with innovativeness in internal communication to interact with their students. They have yet to use internet to monitor and evaluate students' works.

7. $43 \%$ of teachers has problems with innovativeness in external communication to interact with various parties outside the school. They do not build strong relationship with students' parents.

Based on the preliminary survey, it is concluded that in general, teachers in private VHS in Bogor City have problems with innovativeness. In other words, these teachers have not demonstrated good innovation in their teaching process at school. It is a concern because such teachers will generate graduates who cannot innovate in the society. Hence, it is recommended that the schools make some efforts in various fields to improve the quality of their teachers, turning those teachers into innovative ones.

\section{METHODS}

This study is conducted on teachers in private Vocational High Schools (VHS) in Bogor City, West Java Province, Indonesia. Population in this study are 590 permanent teachers of private VHS in Bogor City, who work in 96 schools.

The sample is taken using cluster random sampling. The size of the sample is determined using Slovin's formula, which yields 238 respondents as sample for this study.

This study employs survey methodology with correlational approach. Survey method is designed to gather information about personality and transformational leadership, in their relations to innovativeness in private VHS in Bogor City, West Java Province. Survey method is chosen with consideration that this study is conducted in the present and in a short period of time. In addition, survey method is also selected because it suits the characteristics of the problem being studied and because it is relatively inexpensive.

Data for this study is collected using structured observation technique, employing questionnaires as research instrument. The data is analyzed using statistical analysis, including descriptive analysis of the variables.

As a quantitative research, data analysis in this study involves data processing and data display, calculation to describe data, and hypothesis testing using statistical test on SPSS ver. 25.

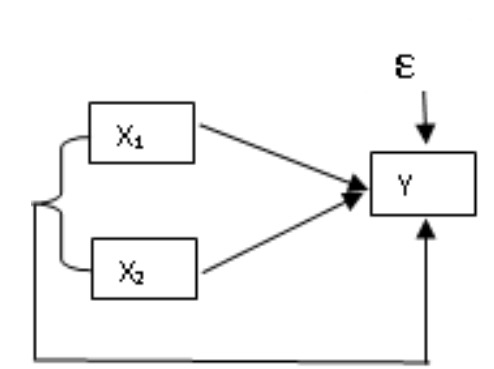

Figure 1. Constellation of Variables

Remark:

$\mathrm{X} 1$ = Personality

$\mathrm{X} 2=$ Transformational Leadership

$\mathrm{Y}=$ Innovativeness

$\varepsilon=$ Others

\section{RESULTS AND DISCUSSION}

a. Correlation between Personality and Innovativeness of Permanent Teachers in Private VHS in Bogor City

The model of correlation between personality and innovativeness can be expressed in a simple linear regression equation $\hat{\mathrm{Y}}=47.669+0.597 \mathrm{X} 1$, which means that every unit of improvement in personality will be followed by 0.597 unit of increase in innovativeness, with a constant of 47.669. The regression equation $\hat{\mathrm{Y}}=$ 
$47.669+0.597 \mathrm{X} 1$ can be used to predict innovativeness score if personality score is known.

Summarizing various definitions of personality, this study defines personality as unique characteristics or traits that are most dominant and relatively stable in an individual, which affect his/her behavioral tendency, thinking pattern, and emotion in interacting with his/her environment. In the personality theory using the Big Five Personality model, there are five dimensions of personality: a) Openness to experience, b) Conscientiousness, c) Extraversion, d) Agreeableness, and e) Emotional Stability.

The findings show that the average total score of indicators in personality variable is 4.1. Based on the empirical score data, this level of personality is relatively good. Data on frequency distribution shows that $43.7 \%$ of teachers have below average personality score.

The coefficient of correlation (ry1) is 0.318 , indicating a weak positive correlation between personality and innovativeness. Personality's contribution to innovativeness is indicated by the coefficient of determination (ry12) of 0.1014, which means that personality variable only contributes $10.14 \%$ to innovativeness, while the remaining $89.86 \%$ is determined by other variables. Therefore, efforts must be made to improve teachers' personality so their personality will have the traits of innovators.

Teachers with 'openness to experience' personality will always try to get new information to satisfy their needs for creativity that supports their innovativeness. Such teachers will not stop even though they have problems with internet connectivity or foreign language. This shows that these teachers also have 'conscientiousness' personality. Teachers with openness to experience and conscientiousness personalities will find any way to satisfy their curiosity and imagination to be creative in teaching.

The weakness identified from these teachers in this study is their lack of individual ambition to pursue personal achievement.
Headmasters should consider this problem and handle it.

b. Correlation between Transformational Leadership and Innovativeness of Permanent Teachers in Private VHS in Bogor City

The model of correlation between transformational leadership variable and innovativeness variable can be expressed in a simple linear regression equation $\hat{\mathrm{Y}}=$ $84.113+0.207 \mathrm{X} 2$; which means that every unit of improvement in transformational leadership will be followed by a 0.207 unit of improvement in innovativeness, with a constant of 84.113. The regression equation $\hat{\mathrm{Y}}=84.113+0.207 \mathrm{X} 2$ can be used to predict innovativeness score if transformational leadership score is known.

The coefficient of correlation (ry2) of 0.261 indicates a positive correlation between transformational leadership and innovativeness. Contribution of transformational leadership is indicated by the coefficient of determination (ry22) of 0.0683 ; which means that transformational leadership contributes $6.83 \%$ to innovativeness, while the remaining $93.17 \%$ is determined by other variables.

Transformational leadership is behaviors that inspire, motivate, improve awareness, anticipate the future, provide examples, and affect changes to the better. Its indicators are idealized influence, inspirational motivation, intellectual stimulation, and individualized consideration (Bass and Riggio, 2006).

One of the keys to improve employees' innovativeness is the leader's behavior. A leader must focus on two aspects: setting a shared vision that aims to inspire and describing the vision into organizational mission and goals. A leader must have the capability to provide detailed planning and explain the importance of achieving work target. Moreover, a leader must always improve his/her leadership and managerial skills (Xie Shunlong and Zhang Weiming, 2012: 87-96).

This is in line with the theory proposed by Colquitt, Lepine, and Wesson (2009) that transformational leadership is a leader's 
behavior that inspires his followers to promise to share visions that are meaningful to their work and that transformational leadership serves as an example which helps the followers to improve their potential and to see a problem from new perspectives. Transformational leaders develop their followers' awareness about the importance of results and goals to be achieved and encourage the followers' confidence that those results and goals are achievable.

Headmaster should encourage teachers to participate in activities that develop their competencies, such as trainings, involvement in Parents-Teachers Association, and representing the school in competitions. Headmaster should encourage cooperation among teachers, through teachers' work group for instance, so that teachers can share and discuss new ideas to be implemented.

This is also in line with the theory proposed by Hellreigel and Slocum (2011: 329), that transformational leadership also involves anticipating future trends, inspiring followers to understand and embrace the possibilities of new visions, developing others to be leaders or better leaders, and building organization or group into a challenging, interesting, and beneficial learning community.

The findings show that the average total score of indicators in transformational leadership variable is 4.05 . Based on the empirical score data, this level of personality is relatively high. Data on frequency distribution shows that $24.4 \%$ of teachers express dissatisfaction with their headmaster's leadership.

c. Correlation between Personality and Transformational Leadership, collectively, and Innovativeness of Permanent Teachers in Private VHS in Bogor City

The model of correlation between personality and transformational leadership variables, collectively, and innovativeness variable can be expressed in a multiple linear regression equation $\hat{Y}=33.492+$ $0.165 \mathrm{X} 1+0.524 \mathrm{X} 2$; which means that every unit of improvement in personality and transformational leadership will be followed by 0.165 and 0.524 unit of improvement in innovativeness, with a constant of 33.49. The regression equation $\hat{\mathrm{Y}}=33.492+0.165 \mathrm{X} 1+0.524 \mathrm{X} 2$ can be used to predict innovativeness score if personality and transformational leadership scores are known.

The coefficient of multiple correlation (ry2) of 0.379 indicates a positive correlation between personality and transformational leadership, collectively, and innovativeness. Collective contribution of personality and transformational leadership is indicated by the coefficient of determination (ry22) of 0.1437; which means that personality and transformational leadership collectively contribute $14.37 \%$ to innovativeness, while the remaining $85.63 \%$ is determined by other variables.

The coefficient of multiple correlation (ry12) of 0.379 shows correlation between personality and transformational leadership, collectively, and innovativeness. Therefore, to increase innovativeness, the effort to improve teachers' personality would be better if it is done together with the effort to improve headmasters' transformational leadership.

According to Wawan (2014: 35), innovation is produced by creative individuals. Creativity requires a thinking process that broaden one's perspective and insight so that he/she can create new ways to solve a problem. Creativity is supported by three components: knowledge, creative thinking, and motivation. In an organization, these three components can be improved through the leader of the organization.

Transformational leaders have certain characteristics. They are able to provide idealized influence, inspirational motivation, intellectual stimulation, and individualized consideration to their followers or employees.

Headmasters motivate teachers to be actively involved in activities (such as Parents-Teachers Association) which can help the teachers to gather necessary information to improve their lesson plans and teaching methods. Headmasters also 
provide teachers with opportunities to participate in trainings to develop their knowledge and personality.

Headmasters also give examples of problem solving and encourage working in work groups, with consideration to the characters and strengths of each teacher. It will motivate teachers to improve their knowledge through information they gather from their peers.

Headmasters provide time for teachers to express their opinions or new ideas that will further improve the organization. Headmasters also spare their time to listen to problems that teachers bring and to consider the possible solutions.

It is clear that personality development through transformational leadership can improve teachers' innovativeness, which will increase their performance and, in turn, the school's quality.

\section{CONCLUSION/RECOMENDATION}

This study was conducted to examine the correlation between personality and transformational leadership variables and teachers innovativeness in private vocational high schools in Bogor City. Based on data analysis, discussion of findings, and hypotheses testing, the following conclusions are drawn:

1. There is a significant and positive correlation between personality variable and innovativeness variable, with coefficion of correlation (ry1) of 0.318 using regression equation $\hat{Y}=47.669+0.597 X 1$. It means that improvement in personality can increase innovativeness. Personality variable contributes $10.14 \%$ to innovativeness, as indicated by the coefficient of determination (ry12) of 0.1014 .

2. There is a very significant positive correlation between transformational leadership variable and innovativeness variable. The coefficient of correlation (ry2) is 0.261 in regression equation $\hat{Y}=$ $84.113+0.207 \mathrm{X} 2$. This indicates that an improvement in transformational leadership can increase innovativeness.

Transformational leadership contributes $6.83 \%$ to innovativeness, as indicated by the coefficient of determination (ry22) of 0.0683 .

3. There is a very significant positive correlation between personality and transformational leadership variables, collectively, and innovativeness variable. The coefficient of correlation (ry12) is 0.379 , based on calculation using the regression equation $\hat{\mathrm{Y}}=33.492+0.165 \mathrm{X} 2$ $+0.524 \mathrm{X} 3$. This indicates that improvement in personality and transformational leadership, collectively, can increase innovativeness. Personality and transformational leadership variables collectively contribute $14.73 \%$ to innovativeness, as indicated by the coefficient of determination (ry232) of 0.1437 .

\section{Recommendations}

1. Teachers should improve their creative thinking skill as a start of innovative behavior. Creative thinking begins with imagination. There are many simple, easy, and inexpensive ways to improve creativity, logical reasoning, and imagination, including a lot of reading and socialization with creative people.

2. Headmaster must provide teachers with opportunities for self-development and support them by providing necessary facilities and infrastructure.

3. Headmaster should encourage teachers to participate in positive and beneficial activities such as inter-school cooperation groups, teachers and parents discussion groups, and trainings.

4. Teachers must be able to manage their time to expand their knowledge and imagination, which will turn into innovative activities. Nowadays, latest knowledge and information is easy to access through the internet. Thus, teachers need to have trainings in computer and time management.

5. Innovative teachers are observant in their school environment. Should their peers 
Muthahharah Thahir, et al. /Journal of Educational Administration Research and Review/Vol. 2

No. 1 June 2018

need help in completing a task, innovative teachers will gladly help them and give necessary suggestions. School programs will be finished easier and faster.

\section{ACKNOWLEDGMENTS}

\section{REFERENCES (Examples)}

Andriopoulos, Constantin and Patrick Dawson, 2009, Managing Change, Creativity and Innovation, Los Angeles: SAGE

Bass, Bernard M., and Ronald E. Riggio, 2006, Transformational Leadership, $2^{\text {th }}$ Ed., Mahwah: Lawrence Erlbaum Associates, Inc.

Bateman, Thomas S., and Scott A. Snell, 2015, Management, Leading and Collaborating in A Competitve World, New York, McGraw-Hill

Buchanan, David A., and Andrzej A. Huczynski, 2010, Organizational Behavior, $7^{\text {th }}$ Ed, Harlow; Pearson

Colquitt, Jason A., Jeffery A. Lepine, and Michael J. Wesson, 2009, Organizational Behavior, Improving Performance and Committment in the Workplace, New York: McGraw-Hill

De Janasz, Suzanne C., Karen O. Dowd, and Beth Z. Schneider, 2012, Interpersonal Skills in Organizations, New York:McGraw-Hill

Feist, Jess and Gregory J. Feist, 2009, Theories of Personality, $7^{\text {th }} E d$., Boston: McGraw-Hill

Garcia, Rosanna \& Roger Calantone, 2002, "A critical look at technological innovation typology and innovativeness terminology: a literature review," The Journal of Product Innovation Management 19, 2002, pp.110-132.

Hellriegel, Don and John W. Slocum, 2011, Organizational Behavior, South-Western Cengeage Learning: Mason

Hollenbeck, John R, and John A. Wagner III, 2010, Organizational Behavior, New York: Routledge

Kreitner, Robert and Angelo Kinicki, 2007, Organizational Behavior, New York: McGraw-Hill

Robbins, Stephen P., and Timothy A. Judge, 2013, Organizational Behavior, $15^{\text {th }}$ Ed., Boston: Pearson Education Limited

Shunlong, Xie and Zhang Weiming, 2012, "The Relationships between Transformational Leadership, LMX, and Employee Innovative Behavior" Journal of Applied Business and Economics, Vol.13 (5)

Act No. 20 Year 2003 on National Education System Act No. 14 Year 2005 on Teachers and Lecturers Wawan Dhewanto, et al., 2014, Manajemen Inovasi, Peluang Sukses Menghadapi Perubahan, Yogyakarta: CV Andi Offset 